\title{
The impact of psychosocial factors on the risk of erectile dysfunction and inhibition of sexual desire in a sample of the Brazilian population
}

\author{
Project Sexuality (ProSex), Department and Institute of Psychiatry, \\ Medical School of the Universidade de São Paulo, São Paulo, Brazil
}

\begin{abstract}
INTRODUCTION
Sexual dysfunctions are represented by disturbances related to sexual desire and psycho-physiological changes in the cycle of sexual response. Such dysfunctions cause great suffering, as well as interpersonal difficulties. ${ }^{1}$

About 30 million men in the United States present some erectile dysfunction that causes suffering and interpersonal difficulties. ${ }^{1-4}$ According to the Massachusetts Male Aging Study (MMAS), ${ }^{5} 52 \%$ of men between 40 and 70 years old present some type of erectile dysfunction. In a recent cross-national study published in 2003, $34 \%$ of Japanese men, $22 \%$ of Malaysians, $17 \%$ of Italians and $15 \%$ of Brazilians were found to present some moderate to severe erectile dysfunction. ${ }^{6}$

The interest in sexual dysfunctions that has arisen both among health professionals and among the general public is partly due to increasing knowledge of the neurovascular mechanisms of the sexual response in men and women..$^{7-9}$ Several types of drugs have been developed for the treatment of erectile dysfunction, while other agents have been suggested for the treatment of inhibition of sexual desire. ${ }^{10-14}$ However, few studies on the origin of these disturbances have investigated psychosocial factors such as unemployment. The increasing risk of erectile dysfunction has been correlated with diabetes, coronary heart disease and smoking. ${ }^{5,6,15-17}$ A risk of erectile dysfunction has also been found among depressed and unemployed men. ${ }^{6,15,18-24}$

Inhibition of sexual desire, defined as the absence of or a severe decrease in fantasies and desires related to any sexual activity, is the most frequent sexual dysfunction among women. ${ }^{17,25-27}$ The prevalence of female inhibition of sexual desire ranges from $5 \%$ to $46 \% .{ }^{25}$ Nathan (1986) found
\end{abstract}

rates of $1 \%$ to $35 \%$ among women with complaints of inhibition of sexual desire in a literature review. ${ }^{28}$ Depression and age are the most common factors in the development of this dysfunction in women, as shown in several studies. ${ }^{29-31}$

The present study shows the frequencies of depression, erectile dysfunction and inhibition of sexual desire in a sample of the Brazilian population, with the aim of evaluating the risk of erectile difficulties and inhibition of sexual desire in relation to depression, unemployment, aging and education level.

METHODS

The Brazilian Study of Sexual Behavior (BSSB) was conducted between February and April 2000, and was performed using a non-random sample of 2,835 subjects ( $53 \%$ were women), from ten cities in seven Brazilian states. ${ }^{32}$ All subjects were aged 18 years or over. The sample was comparable to the general population of Brazil in terms of ethnicity and religion, but had a larger proportion of subjects with higher education levels. ${ }^{33}$ The subjects were weekend visitors to beaches, parks and shopping centers, and they were invited to answer an anonymous self-administered questionnaire.

The original questionnaire was submitted to a pilot test, in which 30 subjects of both sexes answered it. Following adjustments in terms of consistency and reliability, the final questionnaire included questions on demographic data (e.g. age, employment and education level), general health (self-reporting of medical conditions), lifestyle and sexual behavior. The questionnaire has already been published elsewhere. ${ }^{32}$

With regard to the erectile dysfunction assessment, the subjects were requested to choose

\section{ABSTRACT}

CONTEXT: Sexual dysfunctions can have origins in physical, psychological and psychosocial factors.

OBJECTIVE: To describe the frequency of erectile dysfunction (ED) and female inhibition of sexual desire (ISD) in a Brazilian sample, and to estimate the risks of these dysfunctions.

TYPE OF STUDY: Non-random survey.

SETTING: Ten Brazilian cities.

METHODS: 2,835 subjects ( $53 \%$ women) aged over 18 years answered a questionnaire about their general health and sex life. The chi-squared test and multivariate logistic regression were used. Values of $p \leq 0.05$ were considered significant.

RESULTS: The women's average age was 36.6 years $( \pm 13.3)$ and the men's was $39.5( \pm 13.3)$. $14.7 \%$ of men presented moderate/complete ED and $34.6 \%$ of women presented ISD. Depression was mentioned by $16.8 \%$ of men and $29.7 \%$ of women. The chances of having ED and ISD were higher for subjects who had had lower school attainment. Lack of a job and depression gave rise to 1.5 times $(95 \% \mathrm{Cl}: 1.0-2.3)$ and 1.9 times $(95 \% \mathrm{Cl}: 1.2-3.0)$ greater chances of ED respectively. Compared with men aged up to 25 years, those aged $41-60$ had 1.9 times $195 \% \mathrm{Cl}$ : $1.0-3.4$ ) and those aged 61 and over had 5.4 times (95\% Cl: $2.3-12.6)$ greater risk of ED. For women, lack of a job gave rise to 1.5 times $195 \%$ CI: 1.1 - 1.9) greater chance of ISD; depression was not associated with higher risk. Compared with women aged up to 25 years, those aged $41-60$ and 61 or over had, respectively, 2.9 times $(95 \% \mathrm{Cl}$ : $2.0-4.1)$ and 7.5 times $(95 \%$ $\mathrm{Cl}$ : $3.0-18.6)$ greater risk of ISD.

DISCUSSION: Increasing unemployment has affected the whole population, but especially those with lower levels of school attainment. Such levels are positively linked with presence of sexual dysfunctions.

CONCLUSION: Lack of jobs, age and low school attainment are risks for the sexual dysfunctions studied. Depression increased the risk of ED but not female ISD.

KEY WORDS: Impotence. Depression. Education. Unemployment. 
one category that best described them: always, usually, sometimes, or never able to achieve and maintain an erection that was satisfactory for sexual performance. The answers were then used to classify the respondents into one of the following categories: none, minimal, moderate, or complete erectile dysfunction, respectively.

For the assessment of inhibition of sexual desire and depression, subjects were asked to mark with an "X", beside the respective question, if there had been some inhibition or absence of sexual desire or depression during their lives.

The chi-squared test and multivariate logistic regression were used for statistical analysis. Values of $\mathrm{p} \leq 0.05$ were considered statistically significant.

Not all the men or women answered all the items of the questionnaire. Consequently, in presenting the variable studied, the number of subjects who answered this question has been specified. There were no differences between subjects who answered these questions and those who did not.
For the multivariate logistic models, there were 1,257 women and 1,057 men. Only the variables that were part of the main objective of the present study (age, education level, unemployment and depression) have been included. Men and women who did not answer at least one of the questions on age, education level, depression or employment have been excluded from this study. No statistically significant difference was presented between those who were excluded and those included, in relation to the variables studied.

\section{RESULTS}

The average age was 36.6 years (standard deviation, $\mathrm{SD}=13.3$ ) for women and 39.5 years $(\mathrm{SD}=13.3)$ for men.

$41 \%$ of the women and $22.5 \%$ of the men who answered the question about working condition were unemployed. Depression was mentioned by $29.7 \%$ of the women and $16.8 \%$ of the men who answered this questions.

Table 1. Proportion (\%) of depression and sexual dysfunctions (inhibition of sexual desire in women or moderate/complete erectile dysfunction in men) according to age and working status and education attainment by gender

\begin{tabular}{|c|c|c|c|c|}
\hline & \multicolumn{2}{|c|}{ Women } & \multicolumn{2}{|c|}{ Men } \\
\hline & Total & ISD n (\%) & Total & ED n (\%) \\
\hline \multicolumn{5}{|l|}{ Age (years) } \\
\hline Up to 25 & 384 & $90(23.4)$ & 190 & $19(10.0)$ \\
\hline 26 to 40 & 561 & $145(25.8)$ & 493 & $47(9.5)$ \\
\hline 41 to 60 & 455 & $214(47.0)$ & 395 & $71(18.0)$ \\
\hline$>60$ & 74 & $54(73.0)$ & 83 & $32(38.6)$ \\
\hline \multirow[t]{3}{*}{$p$ for trend } & \multicolumn{3}{|c|}{$<0.01$} & $<0.01$ \\
\hline & \multicolumn{2}{|c|}{ Women } & \multicolumn{2}{|c|}{ Men } \\
\hline & Dep n (\%) & ISD n (\%) & Dep n (\%) & ED n (\%) \\
\hline \multicolumn{5}{|l|}{ Working status } \\
\hline Unemployed & $\begin{array}{c}175 / 526 \\
(33.3 \%)\end{array}$ & $\begin{array}{c}189 / 526 \\
(35.9 \%)\end{array}$ & $\begin{array}{l}55 / 263 \\
(20.9 \%)\end{array}$ & $\begin{array}{l}43 / 240 \\
(17.9 \%)\end{array}$ \\
\hline Employed & $\begin{array}{c}202 / 757 \\
(26.7 \%)\end{array}$ & $\begin{array}{c}205 / 757 \\
(27.1 \%)\end{array}$ & $\begin{array}{c}146 / 905 \\
(16.1 \%)\end{array}$ & $3 / 822(11.3 \%)$ \\
\hline \multirow[t]{3}{*}{$p$ for trend } & 0.011 & 0.001 & 0.07 & 0.007 \\
\hline & \multicolumn{2}{|c|}{ Women } & \multicolumn{2}{|c|}{ Men } \\
\hline & \multicolumn{2}{|c|}{$\mathrm{n}(\%)$} & \multicolumn{2}{|c|}{$n(\%)$} \\
\hline \multicolumn{5}{|c|}{ Educational attainment (years) } \\
\hline Less than eight & \multicolumn{2}{|c|}{$118(8.0)$} & \multicolumn{2}{|c|}{$93(7.3)$} \\
\hline Eight & \multicolumn{2}{|c|}{$156(10.6)$} & \multicolumn{2}{|c|}{$138(10.8)$} \\
\hline Eleven & \multicolumn{2}{|c|}{$604(41.1)$} & \multicolumn{2}{|c|}{$537(41.9)$} \\
\hline More than eleven & \multicolumn{2}{|c|}{$591(40.2)$} & \multicolumn{2}{|c|}{$514(40.1)$} \\
\hline$p$ for gender & \multicolumn{4}{|c|}{0.884} \\
\hline
\end{tabular}

$I S D=$ inhibition of sexual desire; $E D=$ erectile dysfunction; Dep = depression.

The total frequency of feminine inhibition of sexual desire was $34.6 \%$ of respondents. For men, $14.7 \%$ had moderate to severe erectile dysfunction.

We observed that unemployed women and men presented higher frequencies of depression, as well as higher frequencies of inhibition of sexual desire and erectile dysfunction, respectively (Table 1).

Both erectile dysfunction and inhibition of sexual desire are directly related to aging. As Table 1 shows, there is a tendency towards higher frequencies of these dysfunctions among older subjects.

The results from the multivariate logistic regression model showed that, for women, being unemployed, getting older and having less than 11 years of school education increased the chance of inhibition of sexual desire (Table 2). Depression did not increase the chance of inhibition of sexual desire and was not included in the final model.

Unemployment, aging, less than 11 years of school education and depression increased the chance of moderate to severe erectile dysfunction among men (Table 2).

DISCUSSIDN

The frequencies of erectile dysfunction and inhibition of sexual desire in our sample were high.

In the medical literature, different prevalences of sexual dysfunctions are found. This variation is due partly to the type of sample studied (community versus sexuality clinics), the type of trial performed (self-administered questionnaires or interview), and the clinical definition used for each dysfunction. ${ }^{25}$

The present study does not represent a sample of all socioeconomic-cultural classes of the Brazilian population, but it can give us an idea of how prevalent sexual dysfunctions are. It can serve as a starting-point for future surveys with a wider-ranging sample of people and also for pointing out possible associations between sexual dysfunctions and depression and other sociodemographic factors.

The same tendency towards increasing erectile dysfunction and inhibition of sexual desire with age that was noticed in previous studies was found in the present sample. $3,6,15,17,24$

Several studies have indicated a relationship between depressive symptoms and erectile dysfunction. These conditions are commonly associated, mutually maintaining or enhancing each other. ${ }^{34-37}$ 
The trend towards increasing unemployment around the world ${ }^{18}$ has affected all levels of the population, especially in Brazil. It has particularly affected those with lower levels of school attainment. On the other hand, lower levels of education are also positively linked with the presence of sexual dysfunctions in the present sample, in the same way as found by Laumann, Paik and Rosen (1999). ${ }^{17}$ In our sample, these two factors worked independently to increase the chances of having the sexual dysfunctions studied. Therefore, the higher risk of sexual dysfunction among unemployed subjects cannot be explained by the low level of school attainment alone.

CONCLUSIONS

Age, unemployment and low levels of school attainment increased the risk of inhibition of sexual desire among women and erectile dysfunction among men independently of each other, in the present sample.

Depression increased the risk of erectile dysfunction, but not female inhibition of sexual desire, which suggests a need for new investigation and analysis.

The results from this study show that, for correct diagnosis and successful treatment of these dysfunctions, emotional factors (depression) and socioeconomic-cultural factors must be assessed alongside physical factors.

Table 2. Odds ratios and $95 \%$ confidence interval $(\mathrm{Cl})$ for female inhibition of sexual desire $(n=1,257)$ and erectile dysfunction $(n=1,057)$, according to age, socialdemographic characteristics and depression*

\begin{tabular}{lcc}
\hline $\begin{array}{l}\text { Variable } \\
\text { Age (years) }\end{array}$ & $\begin{array}{c}\text { Female inhibition of sexual desire } \\
\text { Odds ratio }(95 \% \mathrm{Cl})\end{array}$ & $\begin{array}{c}\text { Erectile dysfunction } \\
\text { Odds ratio }(95 \% \mathrm{Cl})\end{array}$ \\
Up to 25 & 1.0 (reference) & 1.0 (reference) \\
$26-40$ & $1.1(0.8-1.6)$ & $0.9(0.5-1.7)$ \\
$41-60$ & $2.9(2.0-4.1)$ & $1.9(1.0-3.4)$ \\
$>60$ & $7.5(3.0-18.6)$ & $5.4(2.3-12.6)$ \\
Educational attainment (years) & & 1.0 (reference) \\
More than eleven & $1.0($ reference) & $1.8(1.1-2.8)$ \\
Eleven years & $1.3(1.0-1.8)$ & $2.8(1.5-5.3)$ \\
Eight years & $2.4(1.5-3.7)$ & $4.4(2.2-8.7)$ \\
Less than eight & $1.8(1.1-3.0)$ & 1.0 (reference) \\
Working status & & $1.5(1.0-2.3)$ \\
Employed & $1.0($ reference) \\
Unemployed & $1.5(1.1-1.9)$ & 1.0 (reference) \\
Depression & & $1.9(1.2-3.0)$ \\
No & & \\
Yes & &
\end{tabular}

* Data obtained from the Brazilian Study of Sexual Behavior. Results derived from multivariate logistic regression.

Older patients' own characteristics should also be taken into consideration, since the older the subjects are, the more prevalent these dysfunctions are.
This study has confirmed the strong association between sexual dysfunctions, depression and poor socioeconomic conditions such as unemployment and low educational level.
1. APA (American Psychiatric Association). Transtornos Sexuais e da Identidade de Gênero [Sexual Disorders and Gender Identity]. In: APA (American Psychiatric Association). Manual Diagnóstico e Estatístico de Transtornos Mentais [Diagnostic and Statistical Manual of Mental Disorders] (DSM IV). $4^{\text {th }}$ edition. Porto Alegre: Artes Médicas; 1995. p. 467-510.

2. Benet AE, Melman A. The epidemiology of erectile dysfunction. Urol Clin North Am. 1995;22(4):699-709.

3. Feldman HA, Goldstein I, Hatzichristou DG, Krane RJ, McKinlay JB. Impotence and its medical and psychosocial correlates: results of the Massachusetts Male Aging Study. J Urol. 1994;151(1):54-61

4. McDonagh R, Ewings P, Porter T. The effect of erectile dysfunction on quality of life: psychometric testing of a new quality of life measure for patients with erectile dysfunction. J Urol. 2002;167(1):212-7.

5. Araujo AB, Durante R, Feldman HA, Goldstein I, McKinlay JB. The relationship between depressive symptoms and male erectile dysfunction: cross-sectional results from the Massachusetts Male Aging Study. Psychosom Med. 1998;60(4):458-65.

6. Nicolosi A, Moreira ED, Shirai M, Bin Mohd Tambi MI, Glasser DB. Epidemiology of erectile dysfunction in four countries: cross-national study of the prevalence and correlates of erectile dysfunction. Urology. 2003;61(1):201-6.
7. Rajfer J, Aronson WJ, Bush PA, Dorey FJ, Ignarro LJ. Nitric oxide as a mediator of relaxation of the corpus cavernosum in response to nonadrenergic, noncholinergic neurotransmission. N Engl J Med. 1992;326(2):90-4.

8. Burnett AL. Role of nitric oxide in the physiology of erection. Biol Reprod. 1995;52(3):485-9.

9. Park K, Goldstein I, Andry C, Siroky MB, Krane RJ, Azadzo KM. Vasculogenic female sexual dysfunction: the hemodynamic basis for vaginal engorgement insufficiency and clitoral erectile insufficiency. Int J Impot Res. 1997;9(1):27-37.

10. Boolell M, Gepi-Attee S, Gingell JC, Allen MJ. Sildenafil, a novel effective oral therapy for male erectile dysfunction. $\mathrm{Br} \mathrm{J}$ Urol. 1996;78(2):257-61.

11. Heaton JP, Morales A, Adams MA, Johnston B, el-Rashidy R. Recovery of erectile function by the oral administration of apomorphine. Urology. 1995;45(2):200-6.

12. Morales A, Heaton JP, Johnston B, Adams M. Oral and topical treatment of erectile dysfunction. Present and future. Urol Clin North Am. 1995;22(4):879-86.

13. Rosen RC, Ashton AK. Prosexual drugs: empirical status of the "new aphrodisiacs". Arch Sex Behav. 1993;22(6):521-43.

14. Segraves RT, Croft H, Kavoussi R, et al. Bupropion sustained release (SR) for the treatment of hypoactive sexual desire disorder (HSDD) in nondepressed women. J Sex Marital Ther. 2001;27(3):303-16.
15. Akkus E, Kadioglu A, Esen A, et al. Prevalence and correlates of erectile dysfunction in Turkey: a population-based study. Eur Urol. 2002;41(3):298-304.

16. Moreira ED, Lisboa Lôbo CF, Villa M, Nicolosi A, Glasser DB. Prevalence and correlates of erectile dysfunction in Salvador northeastern Brazil: a population-based study. Int J Impot Res. 2002;14(Suppl 2):S3-9

17. Laumann EO, Paik A, Rosen RC. Sexual dysfunction in the United States: prevalence and predictors. JAMA. 1999;281(6):537-44

18. May JL, Bobele M. Sexual dysfunction and the unemployed male professional. J Sex Marital Ther. 1988;14(4):253-62.

19. Morokoff PJ, Baum A, McKinnon WR, Gillilland R. Effects of chronic unemployment and acute psychological stress on sexual arousal in men. Health Psychol. 1987;6(6):545-60.

20. Meisler AW, Carey MP. Depressed affect and male sexual arousal. Arch Sex Behav. 1991;20(6):541-54.

21. Kantor J, Bilker WB, Glasser DB, Margolis DJ. Prevalence of erectile dysfunction and active depression: an analytic cross-sectional study of general medical patients. Am J Epidemiol. 2002;156(11):1035-42.

22. Nurnberg HG, Seidman SN, Gelenberg AJ, Fava M, Rosen R, Shabsigh R. Depression, antidepressant therapies, and erectile dysfunction clinical trials of sildenafil citrate (Viagra) in treated and untreated patients with depression. Urology. 2002;60(2 Suppl 2):58-66. 
23. Shabsigh R, Zakaria L, Anastasiadis AG, Seidman AS. Sexual dysfunction and depression: etiology, prevalence, and treatment. Curr Urol Rep. 2001;2(6):463-7.

24. Morillo LE, Díaz J, Estevez E, et al. Prevalence of erectile dysfunction in Colombia, Ecuador and Venezuela: a population-based study (DENSA). Int J Impot Res. 2002;14(Suppl 2):S10-8

25. Simons JS, Carey MP. Prevalence of sexual dysfunctions: results from a decade of research. Arch Sex Behav. 2001;30(2):177-219.

26. Rosen RC. Prevalence and risk factors of sexual dysfunction in men and women. Curr Psychiatry Rep. 2000;2(3):189-95.

27. Stuart FM, Hammond DC, Pett MA. Psychological characteristics of women with inhibited sexual desire. J Sex Marital Ther. 1986;12(2):108-15.

28. Nathan SG. The epidemiology of the DSM-III psychosexual dysfunctions. J Sex Marital Ther. 1986;12(4):267-81.

29. Hällström T, Samuelsson S. Changes in women's sexual desire in middle life: the longitudinal study of women in Gothenburg. Arch Sex Behav. 1990;19(3):259-68
30. Purifoy FE, Grodsky A, Giambra LM. The relationship of sexual daydreaming to sexual activity, sexual drive, and sexual attitudes for women across the life-span. Arch Sex Behav. 1992;21(4):369-85.

31. Kadri N, McHichi Alami KH, McHakra Tahiri S. Sexual dysfunction in women: population based epidemiological study. Arch Women Ment Health. 2002;5(2):59-63

32. Abdo CHN, Moreira Jr. ED, Fittipaldi JAS. Estudo do comportamento sexual no Brasil - ECOS [Brazilian study of sexual behavior (BSSB)]. RBM Rev Bras Med. 2000;57(11):1329-35.

33. IBGE - Instituto Brasileiro de Geografia e Estatística. Censo Demográfico 2000 - Resultados do Universo. Available from URL: http://www.ibge.gov.br/home/estatistica/populacao/ censo2000/default.shtm. Accessed in: 2004 (Oct 5).

34. Shabsigh R, Klein LT, Seidman S, Kaplan SA, Lehrhoff BJ, Ritter JS. Increased incidence of depressive symptoms in men with erectile dysfunction. Urology. 1998;52(5):848-52

35. Ducrocq F. Dépression et troubles de la fonction sexuelle [Depression and sexual disorders]. Encephale. 1999;25(5):515-6.
36. Intili $\mathrm{H}, \mathrm{Nier} \mathrm{D}$. Self-esteem and depression in men who presen with erectile dysfunction. Urol Nurs. 1998;18(3):185-7.

37. Hartmann U. Psychische Belastungsfaktoren bei erektilen Dysfunktionen. Verursachungsmodelle und empirische Ergebnisse [Psychological stress factors in erectile dysfunctions. Causal models and empirical results]. Urologe A. 1998;37(5):487-94.

Sources of funding: Financial support from Pfizer Laboratories

Conflict of interest: Dr. Fittipaldi is Medical Director of the Brazilian branch of Pfizer Inc., manufacturer of Viagra ${ }^{\circledR}$ Date of first submission: November 10, 2003

Last received: December 2, 2004

\section{AUTHDRS INFDRMATIDN}

Carmita Helena Najiar Abdo, PhD. Associate Professor, De partment of Psychiatry, Medical School of the Universidade de São Paulo. Coordinator of Project Sexuality (ProSex) Institute of Psychiatry, Medical School of the Universidade de São Paulo, São Paulo, Brazil.

Waldemar Mendes de Oliveira Júnior, MD. Assistant Physician Institute of Psychiatry, Medical School of the Universidade de São Paulo, São Paulo, Brazil.

Edson Moreira Júnior, MD. Associate Researcher, Oswaldo Cruz Foundation and Institute. Coordinator of Epidemiology and Statistics Nucleus, Gonçalo Muniz Research Center Bahia, Brazil.

João Afif Abdo, MD. Medical Doctor, Urologist, Hospital Santa Cruz, São Paulo, Brazil.

João Antônio Saraiva Fittipaldi, MD. Medical Manager of Pfizer Laboratories, São Paulo, Brazil.

Address for correspondence:

Carmita Helena Najiar Abdo

R. Gil Eanes, 492

São Paulo (SP) - Brasil - CEP 04601-041

Tel. (+55 11) 5092-5345 - Fax (+55 11) 5543-8338

E-mail: carmita.abdo@uol.com.br

\section{Impacto dos fatores psicossociais para risco de disfunção erétil e inibição do desejo sexual, numa amostra da população brasileira}

CONTEXTO: As disfunções sexuais originam-se de fatores físicos, psicológicos e psicossociais.

OBJETIVO: Apresentar freqüências de disfunção erétil e inibição do desejo sexual feminino em amostra brasileira e estimar riscos destas disfunções.

TIPO DO ESTUDO: Transversal.

LOCAL: 10 cidades brasileiras.

MÉTODOS: 2.835 indivíduos (53\% mulheres), maiores de 18 anos, responderam a um questionário sobre saúde geral e vida sexual. Foram utilizados testes de qui-quadrado e regressão logística multivariada. São significantes valores de $\mathrm{p} \leq 0.05$

RESULTADOS: A idade média foi 36,6 anos (DP $=13,3$ ) para mulheres e 39,5 anos (DP $=13,3$ ) para homens. 14,7\% dos homens apresentavam disfunção erétil moderada/completa (DE) e 34,6\% das mulheres, inibição do desejo sexual (IDS). Depressão foi referida por $16,8 \%$ dos homens e $29,7 \%$ das mulheres. A chance para DE e IDS foi maior para indivíduos com menos anos de escolaridade. Falta de emprego e depressão aumentaram 1,5 vezes $(95 \% \mathrm{Cl} ; 1,0-2,3)$ e 1,9 vezes $(95 \% \mathrm{Cl} ; 1,2-3,0)$ as chances para $D E$, respectivamente. Comparados aos homens com até 25 anos de idade, aqueles com 41 a 60 anos tiveram risco 1,9 vezes maior para $\mathrm{DE}(95 \% \mathrm{Cl} ; 1,0-3,4)$ e 5,4 vezes $(95 \% \mathrm{Cl} ; 2,3-12,6)$ para aqueles com 61 anos ou mais. Para mulheres, a falta de emprego aumentou 1,5 vezes a chance para IDS $195 \%$ $\mathrm{Cl} ; 1,1$ - 1,9); a depressão não aumentou o risco. Comparadas às mulheres com até 25 anos, aquelas com 41 a 60 anos e com 61 anos ou mais têm risco 2,9 vezes maior para IDS $(95 \% \mathrm{Cl} ; 2,0-4,1)$ e 7,5 vezes maior $(95 \% \mathrm{Cl} ; 3,0-18,6)$, respectivamente.

DISCUSSÃO: $O$ desemprego, como tendência mundial crescente, tem afetado todos os níveis da população, especialmente os com baixo nível de escolaridade. Baixos níveis de escolaridade estão correlacionados positivamente à presença de disfunções sexuais.

CONCLUSÕES: Ausência de emprego, idade e baixa escolaridade representam risco para as disfunções sexuais pesquisadas. Depressão aumentou o risco para disfunção erétil, mas não para inibição do desejo sexual feminino.

PALAVRAS-CHAVE: Impotência. Depressão. Educação. Desemprego. 